\title{
O LIVRE-ARBÍTRIO, O SERVO-ARBÍTRIO E A PRESCIÊNCIA DIVINA
}

\author{
Free will, serant-will and god's prescience
}

Sidnei Francisco Nascimento UFMA

\begin{abstract}
Resumo: Erasmo de Rotterdam escreverá a favor do livre-arbítrio e admitirá que a presciência divina seja compatível com a livre iniciativa da vontade. A possibilidade do acordo entre a necessidade e a liberdade estará preservada, e o humanista demonstrará influenciado pelas allegorias de Orígenes, que as passagens contidas nas Sagradas Escrituras concordarão com o livre-arbítrio. Mas, para se contrapor à interpretação que Lutero fazia dos conceitos de presciência divina e necessidade, o humanista discutirá com a escolástica medieval e, se por um lado, concordará com as cinco provas tomistas a respeito de Deus como princípio e causa do mundo, por outro lado, relativizará que a presciência divina seja a causa necessária dos acontecimentos futuros. Dentro desse contexto, Lutero responderá a diatribe de Erasmo e escreverá o servo-arbítrio, demonstrando radicalmente o contrário, isto é, que não haveria nenhuma compatibilidade entre a vontade de Deus e a vontade humana, porque esta foi completamente obscurecida pelo pecado original. O monge de Wittenberg amplificará o mito do pecado original de Agostinho e dirá que o livre-arbítrio nunca serviu para nada.
\end{abstract}

Palavras chave: Erasmo de Rotterdam, Martinho Lutero, Orígenes, Livre-arbítrio, Servo-arbítrio, Presciência Divina

\begin{abstract}
Erasmus of Rotterdam will write in favour of the free will, and will also accept that a divine foreknowledge is compatible with a free initiative of the will. Thus, the possibility of the agreement between the necessity and the freedon will be preserved, and the humanist will demonstrate, influenced by allegories of Origen, that the passages contained in the Holy Scriptures will agree with the free will. However, in order to oppose to Luther's interpretation on the concepts of divine prescience and necessity, the humanist will debate with medieval scholasticism. Erasmus, therefore, will agree with the five proofs of the existence of God as principle and first cause of the world. In this context, Luther responds to the diatribe of Erasmus and writes the servant-will, demonstrating radically the opposite, that is, that there is no compatibility between a will of God and a human will, because it was completely obscured by the original sin. The monk of Wittenberg will amplify the myth of Augustine's original sin and will say that the book had never been useful.
\end{abstract}

Keywords: Erasmus of Rotterdam, Martin Luther, Origen, Free will, Servant-will, divine foreknowledge.

"Frase tão profunda, que em vão a sondamos: o olho vê um mundo, a alma nele encontra um Deus."

(Victor Hugo)

\section{Introdução}

O opúsculo intitulado O livre-arbítrio, escrito por Erasmo de Rotterdam, aparece pela primeira vez em setembro de 1525 , na estação de Outono na cidade de Frankfurt, e se transformaria desde então num grande acontecimento editorial para a época, dadas as circunstâncias. O sucesso editorial se devia às discussões entre Erasmo e Lutero 
referentes à livre iniciativa da vontade, isto é, se a vontade racional e livre possuiria alguma autonomia frente à presciência divina. Temas que refletirão com profundidade o contraste entre o Humanismo e a Reforma. Dois anos depois, como resposta de Lutero aos comentários de Erasmo a favor do livre-arbítrio, ele escreveu O servo-arbítrio, expressão tomada de Agostinho para deixar clara sua posição contrária à diatribe de Erasmo. Assim, em 4 de janeiro de 1526, O servo-arbítrio viria a público pela primeira vez, numa tradução alemã, e deixaria absolutamente claras as proposições de Lutero e da Reforma manifestamente contrárias à ortodoxia católica.

Para exaltar e ratificar o livre-arbítrio, Erasmo se mantinha numa posição que considerava desconfortável, pois teria de tratar de um assunto que daria mais traballho do que frutos. Ele reconhecia que outras vezes filósofos ou mesmo teólogos antigos e modernos já se debruçavam a respeito do livre-arbítrio, mas para ele, esse tema o conduziria a labirintos inextricáveis que o faria se distanciar cada vez mais de seu trabalho de filólogo e exegeta. "Inter difficultates, quae non paucae occurrunt in divinis literis, vix ullus labyrinthus inexplicabilior quam de libero arbitrio."1(ERASMUS, 1910, p. 01) Mas, já que fora conduzido por vários motivos a tomar partido a favor da Igreja Oficial de Roma, mesmo a contragosto, teve de se posicionar contrário à Reforma e consequentemente contra as premissas de Lutero e dos luteranos. Mesmo assim, enfatizava que não se deveria acirrar ainda mais os ânimos num momento tão conturbado por tantas dissidências, perseguições e guerras religiosas, e sugeriu a Lutero que a discussão fosse conduzida com equilíbrio e moderação.

Para o seu intento, o humanista cristão retomará a teologia dos doutores da igreja, principalmente as alegorias de Orígenes, no que se referem aos comentários que o alexandrino desenvolveu acerca da Epístola aos Romanos 8, 30, quando ele próprio considerava compatível a adequação entre a livre iniciativa da vontade com a noção de presciência divina. A seguir, Erasmo deixará a teologia do alexandrino e recorrerá a algumas distinções escolásticas sobre a ação mediata ou imediata de Deus pelas causas segundas, posições que poderíamos reconhecer respectivamente a respeito do princípio de causalidade de Santo Tomás de Aquino para demonstrar que existe um primeiro motor, imóvel, fora e acima do mundo, plenamente suficiente, que nós chamamos de Deus. O humanista ainda permanecerá no âmbito da teologia especulativa para ratificar sua adesão ao livre-arbítrio. No entanto, mesmo insistindo que não gostaria de continuar com este gênero de argúcias, o autor relativizará as proposições dos escolásticos quando esses admitiam a "necessidade da consequência", mas rejeitavam a "necessidade do consequente".

A metodologia utilizada para apresentar essa diatribe será a comparativa. A partir do texto, O livre-arbítrio de Erasmo de Rotterdam desenvolverá uma série de outros temas conexos que se agregarão ao tema principal para ratificar, negar, ou relativizar a liberdade individual em detrimento de sua adequação ou não à presciência divina. Para justificar as posições a favor ou contrárias ao livre-arbítrio o autor retomará os escritos dos autores antigos e modernos para fazer frente aos antropomorfismos e determinismos da teologia de Martinho Lutero, pois, contrário à vontade racional, este afirmava que a natureza humana não possuía dignidade alguma e não saberia fazer outra coisa senão pecar. Ao rejeitar a dignidade dos méritos e das obras, o reformador continuará afirmando que jamais haverá boas obras feitas pelos homens devido à incapacidade de nossas vontades necessariamente malvadas.

\section{Como tratar do problema referente ao Livre-Arbítrio}

O que regerá inicialmente o espírito do debate referente ao livre-arbítrio será sempre o tom moderador. Por esse motivo, Erasmo sugeria que se devesse discutir a

\footnotetext{
${ }^{1}$ Entre as dificuldades, que não são poucas que ocorrem dentro das Sagradas Escrituras, não há labirinto mais inextricável quanto o livre-arbítrio. (Tradução Nossa) ERASMUS. Libero Arbitrio sive collatio. Leipzig. Georg Böhme, 1910, p. 01
} 
respeito do livre-arbítrio sem ódio e que não se tivesse outra intenção senão tornar mais evidente a verdade pela comparação e os argumentos referentes às Sagradas Escrituras.

Hic scio quios protinus obturatis auribus reclamaturos: "A $\nu \omega$ по $\alpha \alpha \mu \widetilde{\iota^{2}}$ Erasmus audet cuim Luthero congredi, hoc est cum elephanto musca? Ad quos placandos, si tantillum silentii licebit impetrare, nihil aliud praefabor in praesentia quam id, quod res est, me numquam iurasse in verba Lutheri.Proinde nemini videri debebat indignum sicubi palam dissentirem ab illo, nimirum, ut nihil alliud, homo ab homine; tantum abest, ut nefas sit de illius aliquo dogmate ambigere, multo minus, si quis veritatis eliciendae studio moderata disputatione cum illo congrediatur. $^{3}$

Erasmo lembrava que, se Lutero podia dar suas opiniões declaradamente em desacordo com as decisões emanadas pelos doutores da Igreja, de todas as escolas, concílios e papas, por que deveriam incriminá-lo por fazer o mesmo, quando, ao contrário de seu opositor, aceitava voluntariamente os decretos da Igreja compreendendo ou não o que ela ordena? "..Ubicumque per divinarum scripturarum inviolabilem auctoritatem et ecclesiae decreta liceat, quibus meum sensum ubique libens submitto, sive assequor, quod praescribit, sive no assequor."로 Posição que manifestava a atitude fideísta de Erasmo, além de criticar negativamente a maneira passional de Lutero e dos reformados de se ligarem à Escritura pretendendo fazer valer as suas opiniões. 0 caráter assertivo e beligerante de Lutero o fazia se distanciar cada vez mais dos humanistas cristãos, isto é, daqueles que ainda mantinhlham acesas as luzes do conhecimento clássico dentro de uma instituição tão degradada. Lutero sabia que perder a adesão desses arautos do cristianismo representaria um prejuízo para a Reforma que estava em curso. No entanto, era difícil conviver com a lógica do "tudo ou nada" de Lutero, ou seja, quem não estivesse a favor da Reforma estaria contra. (LUTERO,1993, p.38) Posição muito temerária para os humanistas cristãos num período tão conturbado.

Erasmo descreve o livre-arbítrio como a força da vontade humana que permite ao homem se empregar ao que conduz à salvação eterna ou dela se afastar. "Porro liberum arbitrium hoc loco sentimus vim humanae voluntatis, qua se possit homo applicare ad ea, quae perducunt ad aeternam salutem, aut ab issdem avertere ${ }^{\prime \prime 5}$ Essa possibilidade da vontade de se voltar de um lado para outro significa que ninguém é conduzido ao mal se não consentir. As indagações que o humanista se faz para ratificar a vontade racional e livre são as seguintes: qual seria a recompensa dos homens quando fazem o bem e censurados em fazer o mal, quando não fazem nada por sua plena vontade, mas agem em tudo por necessidade? Mas, se a vontade se volta para o mal por necessidade, por que Deus lhes imputaria o pecado? Como ficaria a indignação, a infelicidade, a angústia de um homem censurado por fazer o mal, quando ele não faz nada porque quer, mas age em tudo por necessidade? Segundo Erasmo, os admiráveis preceitos contidos nas Sagradas Escrituras ficariam sem sentido, senão se atribui nenhuma responsabilidade à vontade humana, já que tudo estaria entre as mãos de Deus

\footnotetext{
2 "A $\vee \omega$ по $\alpha \mu \tilde{\omega} \nu$ : a contracorrente do rio! Preferimos a tradução literal desta passagem porque expressa a sensação de fragilidade de Erasmo diante das assertivas de Lutero.

${ }^{3}$ Agora compreendia aquelas reclamações que tapavam continuamente meus ouvidos: Erasmo ouvia as declaraçōes de Lutero: a contracorrente do rio! Este é como uma mosca contra um elefante? Para acalmar, e estimar um pouco de silêncio, nada tenho a declarar em sua presença, não compreendo o que diz e jamais protestei contra os seus discursos. Assim, ninguém, em nenhum lugar, se viu obrigado publicamente a discordar daquele (Lutero); todavia nenhuma diferença seguramente deve existir entre nós; que esteja ausente aquela dúvida dogmática, quando extraímos da verdade aquela disputa moderada contra aquele que se declara. (Tradução nossa) (Idem, p. 02.)

${ }^{4}$...Em qualquer lugar que através das Sagradas Escrituras e inviolável autoridade da Igreja que permite e decreta, a qual meu julgamento em toda parte submeto livremente, compreendendo ou não o que prescreverá. (Tradução nossa) (Idem, p. 03)

${ }^{5}$ Por livre-arbítrio compreendemos o emprego da força da vontade humana pela qual o homem pode se aplicar para aquelas coisas as quais o conduzem à salvação eterna ou das mesmas se afastar. (Tradução nossa) (Idem, p. 19)
} 
e em seus desejos insondáveis. Erasmo era da opinião de que não há nenhuma conduta boa ou malvada se tudo existisse por pura e contínua necessidade.

Para fazer frente ao determinismo da teologia de Lutero, o humanista cristão se propõe a resolver o problema a respeito da compatibilidade ou não entre a noção de presciência divina e necessidade. Erasmo argumentava que a presciência divina não suprime a liberdade, pois pensar o contrário seria admitir que tudo o que a vontade quer ou faz aconteceria como causa de uma necessidade universal e perpétua predeterminada pela vontade de Deus. Se a presciência como causa principal de tudo o que advém determinasse necessariamente a nossa vontade, não haveria lugar para a liberdade, mas se, ao contrário, a presciência divina, compatível com a noção de providência, envolvesse todos os acontecimentos suscetíveis de acontecerem ou não, o livre-arbítrio estaria preservado na medida em que as ações humanas, boas ou malvadas, aconteceriam de qualquer maneira. Erasmo dirá, retomando a noção de presciência desenvolvida pela alegoria de Orígenes, que não é pelo fato de que Deus tivesse previsto as ações futuras que elas aconteceriam necessariamente, mas porque Deus, conhecendo antecipadamente o agente da ação, previu necessariamente o que aconteceria. Sendo assim, a presciência não é a causa do que acontecerá, mas o conhecimento intelectual antecipado do encadeamento de causas que virão a acontecer.

\section{Escritura e tradição referente a questão do Livre-Arbítrio}

Para demonstrar sua opinião a favor da conciliação entre o livre-arbítrio e a presciência divina, como filólogo e exegeta, Erasmo irá interpretar a passagem do Êxodo IX,12-16 a respeito do endurecimento do coração do Faraó, insensível aos conselhos de Deus. ${ }^{6}$ Passagem que sem uma alegoria apropriada poderia depor contra a noção de livre-arbítrio, mas, influenciado pela alegoria de Orígenes, Erasmo dirá o contrário. Ao mesmo tempo em que reconhece o castigo impetrado por Deus ao Faraó, mais obstinado em sua malícia do que preocupado em se conduzir à penitência, Erasmo também reconhece que a bondade de Deus, a mesma que tolera o pecador, conduz uns à penitência e rende outros ainda mais obstinados em sua malícia. Ele dirá para exemplificar seu ponto de vista, que a mesma chuva que faz produzir na terra cultivada frutos excelentes, na terra inculta produzirá espinhos e arbustos.

Quoniam autem absurdum videtur, ut deus, quii non solum iustus est, verum etiam bonus, indurasse dicatur cor hominis, ut per illius malitiam suam illustraret potentiam, Origenes libro tertio sic explicat nodum, ut fateatur occasionem indurationis datam a deo, culpam tamen in Pharaonem reiciat, qui sua malitia factus sit obstinatior per haec, per quae debebat at paenitentiam adduci; quemadmodum ex eodem imbre terra culta producit fructum optimum inculta spinas ac tribolos, et quemadmodum ex eodem sole cera liquescit, limus durescit, ita lenitas dei, quae tolerat peccantem, alios adducit ad paenitentiam, alios reddit obstinatiores in malitia. ${ }^{7}$

Observamos nessa passagem que Erasmo não escapa da cosmologia presente na teologia de Orígenes, que admite a bondade essencial de Deus e que não poderia criar senão coisas boas. No entanto, diferentemente das coisas inanimadas, o homem recebeu um princípio de variabilidade que o constitui livre e responsável. Embora Deus tivesse criado uma natureza humana predisposta para o bem, no entanto, devido ao livre-

\footnotetext{
${ }^{6}$ (Idem, p.46)

${ }^{7}$ Porque é um absurdo reconhecer, como Deus, que não é só justo, mas também verdadeiro e bom, como se diz endurecesse o coração dos homens, que por aquela malícia ilustrasse seu poder. Orígenes no livro terceiro explicava o enlace, que manifestava a ocasião do endurecimento dado por Deus, que transferia para o Faraó as suas faltas; do mesmo modo, que da mesma chuva se produz na terra cultivada ótimos frutos, na terra não cultivada, espinhos e plantas espinhosas, como do mesmo solo, a cera derrete, o limão endurece, e assim a bondade de Deus, que tolera o pecado, para uns os conduzem a penitência, para outros, os rendem ainda mais obstinados na malícia. (Tradução nossa) (Idem, p. 47).
} 
arbítrio, a criatura pode negligenciar a bondade divina e deliberar voluntariamente em direção ao mal, conduzida pelos seus próprios interesses. Erasmo nos sugere que foi do Faraó e não de Deus a causa de seu endurecimento e de suas faltas. A exegese desse endurecimento e do correspondente castigo do rei nos sugere que Deus agiu como um médico, ao prescrever uma terapêutica divina que deixando o mal se desenvolver até vir a ser insuportável, provocaria uma repulsão definitiva fazendo com que o homem se curasse completamente de seu mal. Não foi a presciência divina que previu o endurecimento do coração do rei como causa de suas iniquidades, mas, conhecendo antecipadamente a sula propensão para o mal, Deus sabia que tudo iria acontecer necessariamente como havia previsto.

Veremos nesse momento os comentários que Orígenes faz à Epístola aos Romanos 8, 30 para ratificar a ideia de que a presciência divina não se sobrepõe ao livrearbítrio e para observarmos o quanto Erasmo fora influenciado pelas alegorias do teólogo alexandrino. A passagem diz o seguinte: "Aquele que Deus predestinou, também chamou; aquele que chamou também justificou; aquele que justificou, também glorificou." (ORIGENE, 1985, p.388) Antes de alegorizar essa passagem Orígenes lembra que aquele que Deus havia predestinado, também o havia conhecido previamente. Diferentemente de Erasmo frente ao determinismo de Lutero, Orígenes estava vivenciando o conflito com os gnósticos, no que se refere a doutrina das diversas naturezas do homem que atribuía a salvação apenas aqueles que por natureza foram destinados por terem nascidos bons ou maus. Com essa concepção de natureza os gnósticos negavam a força do livre-arbítrio, como a autonomia e a responsabilidade do agente da ação em fazer o bem ou se obstinar cada vez mais em condutas viciosas.

A seguir, Orígenes inverte a mesma citação paulina para fazer frente a refutação dos gnósticos, que aparentemente negariam e sugeririam que a salvação não estivesse ao alcance do homem, mas dependesse exclusivamente da vontade de Deus: aquele que Deus não conheceu previamente, não predestinou: aquele que não predestinou, não chamou; aquele que não chamou, não justificou, aquele que não justificou, não glorificou. Em última instância, o que o alexandrino pretende é relativizar a refutação dos heréticos e a compreensão da maioria, referente à passagem supracitada que suprimiria a força do livre-arbítrio, sem uma exegese apropriada. Para se contrapor àqueles que suprimem a responsabilidade individual e acreditam que a salvação está condicionada à presciência divina, o teólogo alexandrino diz que nem todos aqueles que foram chamados, foram justificados. Nesse momento ele cita Judas, que de fato fora chamado como apóstolo, porém não foi justificado. Ora, se alguém insistisse em dizer que pelo fato ter sido chamado necessariamente teria sido justificado é certo que nesse caso não foi glorificado, isto é, muitos são chamados, mas poucos são eleitos. (Mit.22,14).

Para resolver o problema daqueles que foram chamados e não justificados, Orígenes dirá quie nem todos são chamados segundo o propósito. O alexandrino dirá que existem bons e maus propósitos, sendo que o primeiro diz respeito à boa e sincera vontade de fazer o bem, enquanto o segundo demonstra a má vontade, derivada das faltas e dos vícios. O alexandrino também irá relativizar o chamado de Deus, esperando como pretexto daqueles que reclamariam que não foram justificados porque não foram chamados. Orígenes responderá que Deus chama a todos sem distinção, no entanto, dependerão dos bons ou maus propósitos, e nesse sentido o desejo de salvação e o sentimento religioso estarăo comprometidos com a adesão voluntária e livre no que se refere a nossa salvação ou perdição. Portanto, nem a nossa salvação, quanto a perdição, estarão condicionadas à presciência de Deus. Nem a justificação dependerá unicamente da chamada de Deus, nem o ser glorificado estaria fora de nosso alcance.

Observamos que tanto a alegoria de Erasmo referente ao Êxodo 9, 12-16, quanto a alegoria de Orígenes ${ }^{8}$, referente aos Romanos 8,30, chegaram à mesma conclusão a respeito do acordo entre a presciência divina e o livre-arbítrio: uma coisa não se

${ }^{8}$ ORIGENE. Commento ala lettera ai romani. Introduzione, traduzione e note a cura di Francesca Cocchini. Vol I, libri VII. Casele Monferrato: Marietti, 1985. 
verificará pelo fato de que Deus sabia que aconteceria: mas acontecerá porque foi conhecida por Deus antes que acontecesse. Por exemplo, os profetas predisseram que Judas trairia, e se aconteceu o que eles predisseram foi devido à malícia de seus propósitos, isto é, o delator fora conduzido mais pela cobiça do dinheiro do que pela vontade de estar em comunhão com os apóstolos. Poderia optar e ser uma pessoa de bem, mas fez o contrário. Orígenes e Erasmo pretendem demonstrar que a causa de sua salvação estava nos propósitos de suas próprias ações, e não na presciência divina.

Praesciebat deus et, quod praesciebat, aliquo modo volebat fore, ut Iudas proderet dominum. İtaque si spectes dei praescientiam infallibilem et voluntatem immutabilem, necessário eventurum est, ut Iudas prodat dominum, et tamen Iudas poterat mutare voluntatem suam aut certe poterat non suspcipere voluntatem impiam. ${ }^{9}$

\section{Distinções Escolásticas}

O humanista cristão recorrerá às distinções escolásticas sobre a ação mediata e imediata de Deus pelas causas segundas e irá reconhecer, como Santo Tomás de Aquino, que Deus é um ser necessário, como a razão de ser de todas as coisas, sufficiente a si mesmo, a fonte de toda a perfeição, como ato puro e como existência separada dotada de sabedoria infinita. Erasmo aceitaria as cinco provas tomistas a respeito de Deus como princípio e causa do mundo:

primeira prova: nos diz que Deus seja considerado como o primeiro motor imóvel que sempre operou, move e rege todas as coisas; segunda prova: pretende demonstrar que, como ser necessário, que Deus é a primeira causa independente, plenamente suficiente para sî mesmo e quie produz todas as coisas; terceira prova: que Deus é o soberano ser, que faz existir os contingentes e mesmo assim permanece distinto deles, como razão de sua própria existência: como quarta prova de sua existência, como ser necessário, Deus é a fonte de beleza e plenitude de toda perfeição; e como quinta e última prova: Santo Tomás de Aquino conceberá que o mundo possui duas ordens, uma diz respeito a ordem particular ou à inclinação ou tendência de cadla coisa para o seu próprio fím, e a outra se refere à ordem universal, da qual observamos a admirável harmonia de todas as coisas dirigidas para um fim comum. ${ }^{10}$

Erasmo, em sua diatribe, não examinará se Deus é a causa primeira e suprema de tudo o que advém:

Hic non excutiam, an deus, qui est sine controversia primaria summa causa omnium, quae fiunt, quaedam sic agat per causas secundarias, ut ipse interea nihil agat, an sic agat omnia, ut secundariae causae tantum cooperentur causae principali, tametsi non suint alioqui necessariae. Certe dubitari non potest, quilin deus, si velit, possit omnium secundariarum causarum naturalem effectum in diversum vertere. Videlicet efficere potest, ut refrigeret et humectet ingnis, ut duret et exsiccet aqua, ut obscuret sol, ut rigeant flumina, ut fluant rupes, ut servet venenum, ut interimat cibus...11

\footnotetext{
${ }^{9}$ Deus previu, e o que previu será. Ele previu que Judas poderia caminhar ao seu encontro. Dessa maneira se observa a infalível presciência de Deus e sua imutável vontade; os acontecimentos são necessários, no entanto, Judas poderia se quisesse caminhar em direção ao Senhor, mas também poderia se quisesse mudar sua vontade, ou certamente não executar sua vontade impia. (Tradução nossa) (ERASMUS, 1910, 52)

${ }^{10}$ HUGON, O.P. Os princípios da filosofia de Santo Tomás de Aquino - As vinte e quatro teses fundamentais. Tradução e introdução

de D. Odilão Moura O.S.B. Porto Alegre: Edpucrs, 1992, p. 202-205.

${ }^{11}$ Isso não nos distancia da ideia de que Deus seja sem controversa a causa suma e primeira de todas as coisas que são feitas, e que age pelas causas segundas, e que nada age inteiramente por si mesmo, pois se assim agissem, como se todas as coisas como causas segundas cooperassem com a causa principal, deveríamos admitir, que não seriam de modo algum necessárias. No entanto, certamente não podemos duvidar se que Deus
} 
O humanista argumentará que cada vez que Deus agisse dessa forma teríamos o milagre e, portanto, o que Deus quer nesses casos excepcionais não revela uma lei geral. O que Deus quer por esses acontecimentos excepcionais ele o quer por justas causas, mesmo que, para nós, permaneçam desconhecidas. Assim poderíamos objetar que há uma dupla necessidade que rege os acontecimentos: a primeira nos diz que a presciência divina não falha; e a outra, se refere a Sua vontade que não poderá ser obstruída.

Erasmo ainda permanece no campo das distinções escolásticas e relativiza o ponto de vista daqueles que, para justificar que a presciência divina seja a causa dos acontecimentos que se produzirão necessariamente, admitem a "necessidade da consequência", mas rejeitam a "necessidade do consequente". Para justificar a primeira necessidade, admitem que tudo depende da vontade de Deus para se fazer o que quiser, assim sendo, tudo acontecerá necessariamente como Deus havia previsto. E para justificar a segunda necessidade, os escolásticos admitem que o agente da ação não poderia tomar outra decisão senão aquela que deveria ser tomada, já que estava prevista pelos desígnios de Deus. Os escolásticos reconhecem que, se a vontade de Deus quisesse de toda eternidade a traição de Judas, esta se seguiria necessariamente, mas negam da mesma forma que tivesse traído necessariamente e que sua obra ímpia tivesse nascido de sua vontade perversa. Assim, suas terminologias reconhecem a eficácia e infalibilidade da presciência divina, a vontade imutável de $\mathbb{D}$ eus e a incapacidade de nosso livre-arbítrio.

In his qui rem scholastica subtilitat discutiunt, recipiunt necessitatem consequentiae, consequentis necessitatem reiciunt. Nam his verbis solent explicare, quo sentiunt. Fatentur enim necessario consequi, quod Iudas proditurus fuerit dominum, si hoc ab aeterno voluntate efficaci voluit deus, at negant consequi, quod ideo necessário proditurus sit, cum ex sua prava voluntate susceperit impium negotium. ${ }^{12}$

No entanto, o humanista cristão se pergunta se entre a presciência divina e as ações humanas haveria possibilidade de as coisas acontecerem de outra maneira. 0 futuro poderia ser diferente daquele que fora previsto por Deus? Entre Deus e o homem haveria lugar para a liberdade? Nesse sentido, para rebater a posição dos escolásticos, Erasmo dirá que tudo o que acontece depende de nossa livre escolha, e que quaisquer que sejam nossas decisões elas já haviam sido previamente conhecidas por Deus. Admite-se no âmbito das ações humanas, um campo de possibilidades que, não importa qual, Deus saberá por antecipação a que irá acontecer. Se Judas traiu necessariamente, ele poderia se quisesse fazer diferente do que fez? O humanista responderá que sim, e que também nesse caso seria conhecido pela presciência divina. Há implícita nesse raciocínio uma "lógica dos possíveis" que admite que Deus conhece tudo o que se produzirá ou não. Assim, devemos considerar que, diante desse campo variado de possibilidades, apenas um acontecimento irá se produzir efetivamente e em nenhum caso prefixado pela presciência divina. Deus conhecerá todos os possíveis que serão suscetíveis de acontecer. A providência e a presciência divina se inserem num esquema de causalidades. Como Erasmo se apropria da alegoria de Orígenes, não seria arbitrário

quisesse poderia inverter o efeito natural de todas as causas segundas. Poderia fazer que o fogo refrescasse e molhasse, que a água se endurecesse, que os rios se petrificassem, que as rochas se liquidificassem, que o veneno curasse e o alimento matasse... (Tradução nossa) (ERASMUS, 1910, p. 51)

${ }^{12}$ Com respeito a estes que discutem a matéria com sutileza escolástica, que admitem a necessidade da consequência e rejeitam a necessidade do consequente. Pois estes possuem o hábito de explicar os verbos como sentem. Manifestam, com efeito, o necessário do consequente, que foi Judas o traidor do Senhor, suposto que Deus quis assim para eternizar uma vontade eficaz, mas negam o consequente, que por esta razão seja o traidor necessariamente, que na companhia de sua má vontade tenha suspendido o ímpio negócio. (Tradução nossa) (Idem, p. 52-53) 
nos remeter a uma influência neoplatônica e admitir um mundo coerente, conhecido e dominado pela presciência como atividade do nous divino. (ORIGËNE, 1976, p. 85).

Todas as recomendações de tolerância e moderação que Erasmo fez a Lutero antes do debate referente ao livre-arbítrio não surtiram efeito. O reformador não poupou adjetivos para contra-atacar a pessoa e as proposições de Erasmo em favor do livrearbítrio. Em sula obra, o Servo-arbítrio, Lutero o considera como um irreligioso, impertinente, como uma enguia, porque fica em cima do muro e não toma partido nem do lado da ortodoxia nem dos dissidentes, que só escreve coisas sem valor, rebotalhos e esterco, além de ser um sofista e ímpio. Para Lutero as passagens contidas nas Sagradas Escrituras são claras e não dependem de alegorias como as de Orígenes e Jerônimos para esclarecê-las. E que não havia entre os escritores eclesiásticos quem tivesse tratado as Escrituras divinas de maneira mais inepta e absurda quanto eles.

\title{
Lutero e a Vontade Cativa
}

Veremos, a partir de agora, como Lutero se inseriu nessa discussão. Destacamos a passagem de Paulo 1 Cor. 12,6: Deus opera tudo em todos, para refletirmos a maneira como o reformador se apropriou dessa passagem para se opor à concepção de presciência divina erasmiana. Ora, dirá o reformador, se Deus opera tudo em todos, logo tudo o que acontece, embora nos pareça contingente, acontece de modo imutável e necessário.

\begin{abstract}
Acaso crês que ele tem presciência sem querer ou que quer sem saber? Se tem presciência querendo, sua vontade é eterna e imutável (porque é sua natureza); se quer tendo presciência, seu saber é eterno e imutável (porque é sua natureza). Disso se segue irrefragavelimente: tudo o que fazemos, tudo o que acontece, ainda que nos pareça acontecer de modo imutável e contingente, na verdade acontece de modo necessário e iimutável, se consideramos a vontade de Deus. Pois a vontade de Deus é eficaz e não há como impedi-la, visto que é a própria potência natural de Deus. ${ }^{13}$
\end{abstract}

Não há como compatibilizar presciência e liberdade. Onde há presciência, há necessidade devido à imutável vontade de Deus e à incapacidade de nossa má vontade. Assim sendo, Lutero desconstruirá sistematicamente todas as proposições de Erasmo em favor do livre-arbítrio, em particular, aquelas que dizem respeito ao endurecimento do coração do Faraó, à delação de Judas e, consequentemente, sua refutação à "necessidade da consequência" e à "necessidade do consequente".

A respeito da exegese do endurecimento do coração do Faraó, o reformador se oporá categoricamente à alegoria de Erasmo e nos dirá que o Faraó não podia fazer diferente do que fez devido a sua vontade e natureza má e viciosa.

Deus opera o mal em nós, por meio de nós, não por culpa de Deus, por causa de um vício nosso, pois somos maus por natureza, e Deus, ao contrário, é bom; ao apropriar-se de nós por meio de sua ação de acordo com a natureza de sua onipotência, ele, que é bom, não pode agir de outro modo senão fazendo o mal com um instrumento mau, ainda que faça bom uso desse mal de acordo com sua sabedoria para sua glória e nossa salvação. ${ }^{14}$

Lutero não duvidava de que Judas fez o que fez porque Deus havia previsto. Se Deus teve a presciência de que Judas cometeria a traição ou que poderia fazer o contrário, aconteceria necessariamente aquilo de que Ele previu, e, portanto, ficaria demonstrado que o livre-arbítrio não é nada. Assim, seria impossível estabelecer um acordo entre a presciência de Deus e a vontade livre, já que a presciência é necessária.

${ }^{13}$ LUTERO, M. Da Vontade Cativa Tradução de Luís H. Dreher, Luís M. Sander e Ilson Kayser.

São Leopoldo: Sinodal ,1993, p. 31 .

${ }^{14}$ Idem, p. 129 
Não há nenhuma cooperação do homem com Deus para a obra da salvação. Não há uma vontade que pode caminhar de um lado para o outro, isto é, que possa contribuir em determinadas circunstâncias para o bem ou para o mal. Só há uma via de mão única, quero dizer, a vontade só faz o mal devido à natureza humana desgraçada e insuficiente. Do ponto de vista da justificação, em que, segundo a alegoria de Orígenes, só serão justificados e glorificados segundo os bons propósitos, para o reformador isso é um absurdo, pois não há dignidade nos méritos, na medida em que tudo o que o ser humano faz é por si mesmo pecado. Se a vontade faz alguma coisa boa o faz sem saber. Tudo o que fazemos, segundo o reformador, é por pura necessidade.

Dessa forma, mesmo sem saber, Lutero se aproximava da opinião dos escolásticos no que se referia ao livre-arbítrio quando concordava com a necessidade da consequência e, ao mesmo tempo, rejeitava a necessidade do consequente. Isso significa que o resultado de nossas deliberações e ações não poderia ser diferente do que já estava previamente determinado por Deus. Aliás, desse modo, o reformador afirmava a consequência da recompensa e, de nenhum modo, a dignidade do mérito. Além do livrearbítrio, o que estava em discussão era a interpretação que se fazia das Sagradas Escrituras. Erasmo e Orígenes concordavam que há passagens obscuras nos livros sagrados que, por esse motivo, precisavam de uma alegoria apropriada. A catequese que Orígenes desenvolveu na Escola de Alexandria tinha como objetivo ensinar a maioria dos preceitos cristãos por meio de alegorias que lhes orientariam para o bem, e a caridade, tornando mais palatáveis aquelas passagens que dizem respeito à ira, aos castigos de Deus e à eternidade do mal. Lutero não tinha dúvidas quanto ao que diziam as Escrituras. Para ele estava absolutamente claro que Deus castiga:

A solução para toda esta questão insolúvel se resume numa só palavrinha: depois desta vida existe outra vida na qual tudo o que não for punido e remunerado aquii será punido e remunerado lá, vissto que a presente vida nada mais é do que a precursora, ou melhor, o início da vida futura. ${ }^{15}$

Lutero concordava que em questões religiosas, para combater à tirania dos pontífices, e a consequente hipocrisia do prelado, caso fosse necessário, reduziria o mundo ao caos envolvendo a multidão em tumultos. O reformador diz a Erasmo em sua obra "Da Vontade Cativa":

Por isso te digo, e rogo que guarde isto no fundo da mente: nessa causa eu viso uma coisa séria, necessária e eterna, de tal espécie e importância que é necessário afirimá-la até a morte, mesmo que o mundo todo não só tivesse que ser envolto em conflito e tumulto, mas também ruísse num só caos e fosse reduzido ao nada. Se não compreendes ou não és afetado por isso, tirata de tuas coisas e deixa que o compreendam e sejam afeados aqueles aos quais Deus o deu. ${ }^{16}$

\section{Conclusão}

Erasmo concluirá sua diatribe tendendo para uma posição moderada. Ele nos diz que não devemos curar um membro luxado torcendo-o no sentido oposto, mas o remetendo no lugar. "...neque sic medendum membro luxato, ut in diversas parte detorqueas, sed in suum locum erat reponendum..." ${ }^{17} \mathrm{O}$ humanista considera que, mesmo imperfeitos, os homens podem fazer boas obras. No entanto, para não serem arrogantes ou pretensiosos diante de suas obras meritórias e não acharem que por esse motivo já seriam justificados e eleitos por Deus, ele nos lembra que aprova a opinião daqueles que concedem qualquer coisa ao livre-arbítrio, mas muito mais a graça. "Mihi

\footnotetext{
${ }^{15}$ Idem, p. 214 .

${ }^{16}$ Idem, p. 38.

17 ...assim, não se cura um membro luxado, torcendo em diversas partes, mas o recolocando em seu lugar... (Tradução nossa) ERASMUS. Libero Arbitrio sive collatio. Leipzig: Georg Böhme, 1910, p. 01
} 
placet illorum sententia, qui nonnihil tribuunt libero arbitrio, sed gratiae plurimum. ${ }^{\text {"18 }}$ (Idem) Com isso Erasmo pretende afastar o sentimento de excessiva segurança e estimular nossos esforços. Para rebater as dúvidas de Lutero, já que sua posição moderada concedeu muito mais à graça do que ao livre-arbítrio, o humanista se utilizou de um exercício retórico e se perguntava: Mas, para que serve o livre-arbítrio se ele não faz nada? Ele mesmo responde com outra indagação: mas para que serve ser totalmente homem se Deus opera em nós como o artesão com sua argila ou com uma rocha? "Ad quid valet totus homo, si sic in ello agit deus quemadmodum figulus agit in luto et quemadmodum agere poterat in silice?"19

Erasmo, como Lutero, rejeita a excessiva confiança nos méritos e nas obras, e ambos confiam completamente em Deus e em suas promessas. No entanto, diferentemente do reformador, o humanista admitirá que, para evitar a desesperança e estimular as boas obras, ele confia na natureza humana, na capacidade da vontade racional e livre de se voltar voluntariamente para o Criador e ser agradável a Deus por meio das obras meritórias. A diatribe de Erasmo conceberá um acordo de cooperação entre o lhomem e Deus, enquanto o servo-arbítrio de Lutero admitirá que a vontade racional fora completamente obscurecida pelo pecado original, e quanto maior a onipotência divina, maior será a sua incapacidade de fazer o bem. Como argumentador e não como juiz, Erasmo nos diz que propôs a discussão com equidade - agora caberá aos outros julgarem.

\section{Referências}

ERASMUS. De libero arbitrio [diatribe] sive collatio. Leipzig: Georg Böhme, 1910.

ÉRASME. Le Libre Arbitre. Tradução de Godin A. Paris: Robert Laffont, 1992.

HUGON, O.P. Os princípios da filosofia de Santo Tomás de Aquino - As vinte e quatro teses fundamentais. Tradução e Introdução de D. Odilão Moura O.S.B. Porto Alegre: Edpucrs, 1988.

LUTERO, M. Da Vontade Cativa. Tradução de Luís H. Dreher, Luís M. Sander e Ilson Kayser. São Leopoldo: Sinodal, 1993.

ORIGÈNE. Philocalie 21-27. Chapitre 25. Prescience et liberté. Introduction, texte, traduction et notes par Éric Junod. Paris: Du Cerf, 1976.

ORIGENE. Commento alla lettera ai romani. Introduzione, traduzione e note a cura di Francesca Cocchini. Vol II, libri VII. Casale Monferrato: Ed. Marietti, 1985.

Doutor em Filosofia (PUC-SP, 2006) Professor Associado de Ética e Filosofia Política do Departamento de Filosofia da Universidade Federal do Maranhão Professor do PPG Filosofia/UFMA Email: sidneifn@bol.com.br

${ }^{18}$ Agrada-me aquelas sentenças que alguns atribuem ao livre-arbítrio, porém muito mais a graça. (Tradução nossa) (Idem p. 17)

${ }^{19}$ Para que vale todos os homens, se Deus age neles como o artesão faz com a argila ou como poderia fazer com a pedra? (Tradução nossa) (Idem p. 91.) 